\title{
Land Use Land Cover Dynamics at Bilate Alaba Sub-watershed, Southern Ethiopia
}

\section{${ }^{* 1}$ MATHEWOS, M; ${ }^{2}$ DANANTO, M; ${ }^{3}$ ERKOSSA, T; ${ }^{4}$ MULUGETA, G}

\author{
${ }^{*}$ School of Plant and Horticulture Science, Hawassa University, Ethiopia \\ ${ }^{2}$ School of Biosystems and Environmental Engineering, Hawassa University, Ethiopia \\ ${ }^{3}$ Internationale Zusammenarbeit (GIZ) GmbH, Ethiopia \\ ${ }^{4}$ College of agriculture and Natural Resources, Dilla University, Ethiopia \\ *Corresponding Author Email: godebo09@gmail.com
}

\begin{abstract}
This study was intended to detect land use/land cover changes over 44 years in the Bilate Alaba Subwatersed, Southern Ethiopia. Four Landsat images (1972, 1986, 2008 and 2017) were used to as inputs to produce four land cover maps of the subwatershed; ERDAS imagine and ArcGIS software were utilized to accomplish the analysis. In the period between 1972 to 1986 cultivated and settlement showed an incremental change by 280.91 and 71.43 ha respectively, while bare land and shrub \& grass land decreased by 225.26 and 140.25 ha respectively. In the period 1986 to 2008 cultivated and bare land increased by 105.13 and 52.90 ha while forest and shrub \& grass land decreased by 103.41 and 50.84 ha respectively. Between 2008 and 2017 settlement and bare land increased by 83.20 and 65.54 ha respectively while shrub \& grass land and forest land decreased by 112.59 and 46.16 ha respectively. The results showed that cultivated land and settlement land expanded by $67.38 \%$ and $532 \%$ respectively whereas forest land, shrub land \&grass land declined by $66.35 \%, 18.36 \%$ respectively over the analysis period (1972-2017). There should be appropriate rural land use/management policy by identifying proper land for specific purpose so that degraded lands would not put under cultivation.
\end{abstract}

DOI: https://dx.doi.org/10.4314/jasem.v23i8.16

Copyright: Copyright (C 2019 Mathewos et al. This is an open access article distributed under the Creative Commons Attribution License (CCL), which permits unrestricted use, distribution, and reproduction in any medium, provided the original work is properly cited.

Dates: Received: 20 August 2019; Revised: 23 August 2019; 28 August 2019

Keywords: Land use, Land cover, GIS, Landsat

Land use is the most permanent form of global environmental change phenomena occurring at both temporal and spatial scales (Wubie etal., 2016), land use management interact with individual decision making contributed to recent land use changes at global level (Lambin et al., 2003). LULC change can affect various natural, social, cultural practices and influenced natural disasters including flooding and earth quakes; vary ecosystem services and enhanced soil erosion (Vitousek etal., 1997; Mass et al., 2004). This calls attention for continuous monitoring of the LULC changes at country,watershed levels. Updating the databases in relation to LULC provide important key to evaluate change scenarios at watershed, regional, to global scales (Prenzel, 2004; Giri et al., 2005). With an area of $1,130,000 \mathrm{~km}^{2}$, Ethiopia is experiencing huge LULC dynamics from natural vegetation to farming practices and human settlement (Kidanu, 2004; CSA, 2007). The problem of land cover dynamics is more severe in the highlands, which account nearly $44 \%$ of the country's landmass and have been cultivated for millennia (Eshetu and Högberg, 2000; Hurni et al., 2005). The use and management of natural resources, and returning the vast degraded landscapes to protective and/or productive systems, have substantial importance to attain the goal of sustainable development in Ethiopia (Lemenih and Teketay, 2004). Few studies have been conducted to estimate and monitor LULC changes in different parts of the Ethiopian highlands (Abate, 1994; Rembold et al., 2000; Tekle and Hedlund, 200). These studies have shown heterogeneity in direction, pattern, type, and/or magnitude of LULC changes in the country. For instance, Zeleke and Hurni (2001) reported a sharp decrease of forest cover while (Bewket, 2002; Fentahun and Gashaw, 2014) found the opposite, in terms of magnitude for changes, Zeleke and Hurni (2001) reported an increase in cultivated lands by $38 \%$ in 38 years (1957-1995). On the other hand, Belay (2002) reported an increase in croplands only by $5.5 \%$ in 43 years (1957-2000). Similarily, other studies (Yizengaw, 1994; Mohammed, 2004; Kassa and Mulu, 2012; Gizachew, 2014; Ayalew, 2008; Girma and Hassen, 2014; Babiso et al., 2016) were conducted to detect LULC changes for a given use across different part of the country. In Southern Ethiopia, limited numbers of studies have been conducted on LULC dynamics. Even the few studies conducted in Southern Ethiopia have not so far been studied in particular focus to Bilate Alaba 
Subwatershed. Therefore, this study was aimed to detect land use land cover change in Bilate Alaba subwatershed, Southern Ethiopia for the period of 1972-2017.

\section{MATERIALS AND METHODS}

Study area: Bilate Alaba Subwatershed located in Alaba Special woreda, Southern Ethiopia about 310 $\mathrm{km}$ south of Addis Ababa and about $85 \mathrm{~km}$ southwest of the Southern Nations Nationalities and Peoples Regional (SNNPR) State capital of Hawassa. The subwatershed is geographically located UTM coordinates of 387500 to $413750 \mathrm{~m}$ north latitude and 797000 to $824500 \mathrm{~m}$ east longitude, the total area of Subwatershed is about 40,300 ha (Figure 1). The elevation ranges from 1554 to $1940 \mathrm{~m}$ above seas level, but most of the sub-watershed is found at about 1800 meter above sea level.

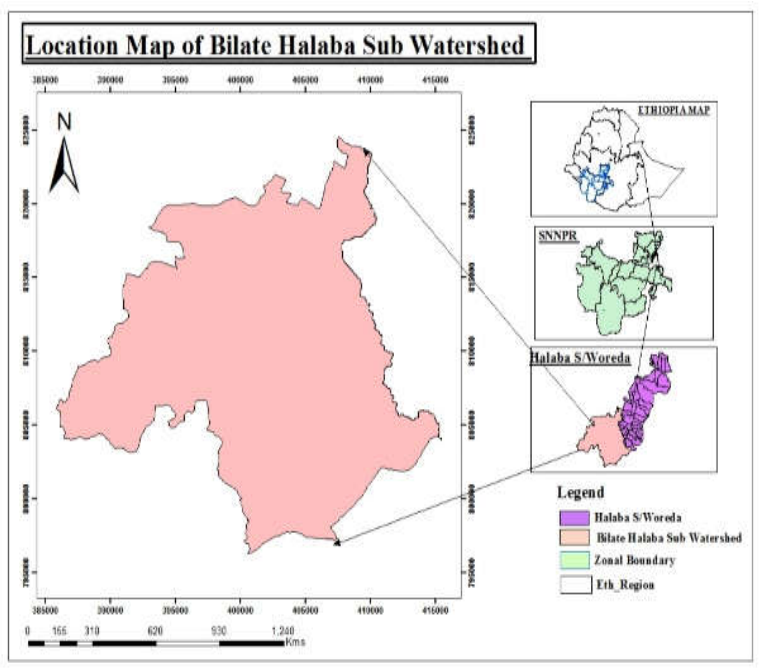

Fig 1. Location map of the study area

According to FAO/UNISCO Classification system the major soils of the Subwatershed are Andosol (Orthic), Chromic Luvisols (Orthic), Phaeozem (Orthic) and Nitisol (Umbric). The soils of the area are believed to be relatively fertile and during good rains farmers can harvest good yield even without fertilizer application. Huge gullies are observed towards the south western end of the watershed, where soils are totally removed beyond recovery. This is believed to have been aggravated due to the easily detachable nature of the soil (IPMS, 2005).

Agro-ecologically, the sub-watershed is characterized as Subtropical zone having the mean precipitation of $1093 \mathrm{~mm}$ per year and the average annual temperature value of $21^{\circ} \mathrm{C}$, mean temperatures also vary from 15 ${ }^{\circ} \mathrm{C}$ to $29^{\circ} \mathrm{C}$. The study area receives a bimodal rainfall where the small rains are between March and April while the main rains are from July to September. The reliability of the small rains is low that farmers do not or mainly raise pepper seedling to be transplanted during the main rains. However, during the main rains, all crops grown in the area are planted, including maize, teff, pepper, haricot bean, sorghum and millet. Rainfall during the main rains are erratic that most of the time crops fail due to un even distribution of rainfall over the growing period.

Data Sources and Materials: The data used in this study were remotely sensed images. Four dates (1972, 1986, 2008 and 2017) of landsat images were acquired and their descriptions are summarized in Table 1. ERDAS Imagine 14.0 and ArcGIS 10.1 software for analysis and mapping was utilized. Moreover, the 1:50,000 topographic map was scanned, georeferenced and merged to obtain a consistent set of baseline information. These maps allowed the verification of LULC delineation using additional point information and linear features vis-à-vis contours, roads and rivers. The dates of all images were chosen to be as closely as possible in the same cropping season and from comparable climatic conditions.

Image Processing and Classification: Assessment of LU/LC dynamics was done by adopting a classification scheme for the Landsat images and carrying out a supervised classification. For this reason, the maximum likelihood classifier for the spectral classification of the landsat images was used. The classification method assumes that statistics for each LULC class is normally distributed and thus groups pixels into a specific class that has maximum probability (Jensen, 2007). Images chosen from the same season can also reduce the misclassification.For this study, five land use and land cover types were identified for the purpose of mapping (Table 2), some land use and land cover classes was required frequent field visits and discussion with farmers and consulted secondary data to have clear understanding on the major categories of LULC. Moreover, the topographic maps with scale of 1:50, 000 and vector data to assist in field investigations and accuracy assessment of the image classification.

Accuracy Assessment: In parallel to the remote sensing work; field work wa s carried out to collect data for Ground Control Points (GCPs). To evaluate the accuracy of the classification system, 660 GCPs were collected using Geographical Position System (GPS) from the field and Google Earth. In this study, the overall accuracy, producers and users accuracy and Kappa coefficient analysis were considered to perform classification accuracy assessment based on error matrix analysis. The error matrix is expressed 
in terms of user's accuracy and producer's accuracy while Kappa coefficient is a measure of the interpreter agreement (Foody, 2002). The producer's accuracy and user's accuracy was calculated based on confusion matrix including overall accuracy and Kappa coefficient (Congalton and Green, 1999). Total accuracy, and Kappa statistics were computed, all the output maps have to meet the minimum $85 \%$ accuracy (Anderson et al., 1976). Areas that are converted from each one class to any of the other classes were computed and direction changes were also determined.

Table 1: Description of remote sensing data that were used in the Study

\begin{tabular}{llllll}
\hline Image & Path & Row & Pixel Size $(\mathrm{m})$ & Observation Date & Source \\
\hline Landsat MSS & 181 & 55 & $30 * 30$ & 1972 & USGS $^{*}$ \\
Landsat TM & 169 & 55 & $30 * 30$ & 1986 & USGS \\
Landsat TM & 169 & 55 & $30 * 30$ & 2008 & USGS \\
Landsat TM & 169 & 55 & $30 * 30$ & 2017 & USGS \\
\hline
\end{tabular}

* United State of Geological Survey

Table 2: Description of Land Use and Land Cover Types Identified

\begin{tabular}{|c|c|}
\hline Land Use and Land Cover & Classes \\
\hline Forest land & $\begin{array}{l}\text { Land covered with relatively tall trees, at least have } 20 \% \text { canopy } \\
\text { coverage including integral open space and felled areas that } \\
\text { mainly eucalyptus trees, and not found near river courses }\end{array}$ \\
\hline Shrub \& grassland & Areas with a cover of shrubs and short trees mixed with grasses. \\
\hline Bare land & $\begin{array}{l}\text { Areas with a cover of stunted and scant grass, and wastelands } \\
\text { with exposed rocks and badlands. }\end{array}$ \\
\hline Cultivated land & $\begin{array}{l}\text { Areas allotted to extended rain fed crop production, mostly } \\
\text { cereals and pulses are managed }\end{array}$ \\
\hline Settlement & $\begin{array}{l}\text { Area which is mainly coved by structures, which included towns } \\
\text { and rural villages }\end{array}$ \\
\hline
\end{tabular}

\section{RESULT AND DISCUSSION}

The LULC maps of Bilate Subwatershed for four reference years are summarized for different land use types were presented in Table 3. The accuracy assessment was conducted for all classified imageries using standard method. The user's, producer's, total accuracy and the kappa coefficients were computed. In general all the maps met the recommended minimum 85\% accuracy (Anderson et al., 1976; Table 3). In all study years much of the Subwatershed coverage was the shrub and grass land (Table 4 and Figure 2, 3, 4 \& 5 ); while the classes of shrub \&grass land and cultivated land comprised the largest share of the total area. The study revealed the forest land was intact in the first study period while overtime decreasing trends of conversion of forest land to agriculture was observed. As a result, the share of cultivated land increased from $23.1 \%$ (9402.48ha) in 1972 to $33.79 \%$ (13745.20 ha) in 1986, to $38.82 \%$ (15648 ha) in 2008 to $39.14 \%$ (15728ha) in 2017. Expansion in the extent of settlement also followed the same trend as cultivated land did, and its area coverage in 2017 was about 6.3 times higher than its original cover of 1972 (Table 4 and Figure 3).

Table 3: LULC classes and accuracy assessment of classified images of Bilate Subwatershed

\begin{tabular}{|c|c|c|c|c|c|c|c|c|}
\hline \multirow[b]{3}{*}{ Classes } & \multicolumn{8}{|c|}{ Accuracy (\%) } \\
\hline & 1972 & & 1986 & & 2008 & & 2017 & \\
\hline & Producers & Users & Producers & Users & Producers & User's & Producers & Users \\
\hline Forest Cover & 93.94 & 96.88 & 100.00 & 97.06 & 100.00 & 100.00 & 100.00 & 100.00 \\
\hline $\begin{array}{l}\text { Shrub and Grass } \\
\text { land }\end{array}$ & 96.97 & 82.05 & 96.97 & 86.49 & 93.94 & 79.49 & 100.00 & 86.84 \\
\hline Settlement & 75.76 & 100.00 & 78.79 & 100.00 & 90.91 & 96.77 & 90.91 & 93.75 \\
\hline Bare Land & 100.00 & 89.19 & 96.97 & 94.12 & 90.91 & 100.00 & 72.73 & 96.00 \\
\hline Cultivated Land & 96.97 & 100.00 & 100.00 & 97.06 & 84.85 & 87.50 & 96.97 & 86.49 \\
\hline Overall coefficient & 92.73 & & 94.55 & & 92.12 & & 92.12 & \\
\hline Kappa coefficient & 0.91 & & 0.93 & & 0.90 & & 0.90 & \\
\hline
\end{tabular}

Table 4: Areas of LULC of Bilate Alaba Subwatershed between 1972 and 2017

\begin{tabular}{|c|c|c|c|c|c|c|c|c|}
\hline & \multicolumn{2}{|l|}{1972} & \multicolumn{2}{|l|}{1986} & \multicolumn{2}{|l|}{2008} & 2017 & \multirow[b]{2}{*}{$(\%)$} \\
\hline & Area (ha) & $(\%)$ & Area (ha) & $(\%)$ & Area (ha) & $(\%)$ & Area (ha) & \\
\hline Cultivated land & 9402.48 & 23.35 & 13335.20 & 33.12 & 15648 & 38.83 & 15738.3 & 39.06 \\
\hline Settlement & 318.0 & 0.79 & 1318 & 3.27 & 1262.34 & 3.13 & 2011.1 & 4.99 \\
\hline Shrub \& Grass Land & 22303.5 & 55.39 & 20340 & 50.51 & 19221.6 & 47.70 & 18208.3 & 45.19 \\
\hline Forest Cover & 3777.48 & 9.38 & 3961.44 & 9.84 & 1686.4 & 4.18 & 1270.93 & 3.15 \\
\hline Bare Land & 4467.97 & 11.10 & 1314.36 & 3.26 & 2478.15 & 6.15 & 3068 & 7.61 \\
\hline
\end{tabular}




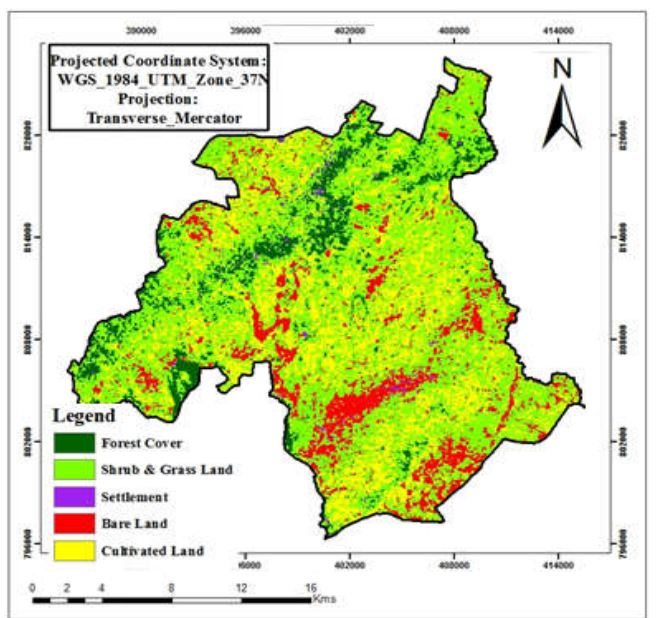

Fig 2. Land use/Land cover map of Bilate Alaba Subwatershed, 1972
On the contrary, the forest land cover declined continuously from its level of $9.28 \%$ in 1972 to $4.16 \%$ in 2008 , further to $3.15 \%$ in 2017 . Similarly shrub and grass lands declines from its level of $55.39 \%$ in 1972 to $50.51 \%$ in 1986 to $47.70 \%$ in 2008 , further to $45.19 \%$ in 2017 . However, areas of settlement and bare land showed inconsistent trends of conversions (Table 4). The land use change matrices depict the changes in extent and directions in LULC classes. As evident from Table 5, there has been substantial increase in the area of cultivated land $(13,335.16$ ha) during 1972-1986, although some portion of its extent was converted to bare land (171.72 ha), to forest land (461.16 ha), to shrub \& grass land (4632.84 ha) and to settlement (340.92 ha).

Table 5: LULC Change Matrices of the Bilate Subwatershed (1972-1986)

\begin{tabular}{|c|c|c|c|c|c|c|c|}
\hline \multirow{8}{*}{ 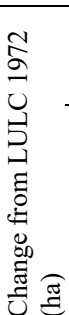 } & & \multicolumn{6}{|c|}{ Change to LULC 1986 (ha) } \\
\hline & LULC & $\begin{array}{l}\text { Shrub } \\
\& \text { Grass Land }\end{array}$ & $\begin{array}{l}\text { Forest } \\
\text { Cover }\end{array}$ & Settlement & $\begin{array}{l}\text { Cultivated } \\
\text { Land }\end{array}$ & Bare Land & Total \\
\hline & Shrub \&Grass Land & 11925.36 & 2297.16 & 706.68 & 7245.72 & 538.56 & 22713.48 \\
\hline & Forest Cover & 1477.80 & 1064.52 & 150.84 & 1027.08 & 57.24 & 3777.48 \\
\hline & Settlement & 104.40 & 9.36 & 30.96 & 141.48 & 32.04 & 318.24 \\
\hline & Cultivated Land & 4632.84 & 461.16 & 340.92 & 3795.84 & 171.72 & 9402.48 \\
\hline & BareLand & 2199.96 & 129.24 & 88.92 & 1535.04 & 514.80 & 4467.96 \\
\hline & Total & 20340.36 & 3961.44 & 1318.32 & 13335.16 & 1314.36 & \\
\hline
\end{tabular}

Table 6: LULC Change Matrices of the Bilate Subwatershed (1986-2008)

\begin{tabular}{|c|c|c|c|c|c|c|c|}
\hline \multirow[b]{2}{*}{ ஜ } & & \multicolumn{6}{|c|}{ Change to LULC 2008 (ha) } \\
\hline & & Shrub & Forest & Settlem & Cultivate & Bare & \\
\hline$\vec{u}$ & LULC & \&Grass Land & Cover & & d Land & Land & Total \\
\hline 5 & Shrub \&Grass Land & 10458.81 & 657.45 & 564.12 & 7175.43 & 1367.37 & 20223.18 \\
\hline$\vec{\varepsilon}$ & Forest Cover & 2211.30 & 823.23 & 88.38 & 689.04 & 110.52 & 3922.47 \\
\hline : & Settlement & 509.67 & 19.80 & 85.41 & 612.72 & 81.72 & 1309.32 \\
\hline$\therefore$ & Cultivated Land & 5744.34 & 157.14 & 443.43 & 6875.55 & 432.27 & 13652.73 \\
\hline च & Bare Land & 259.56 & 16.29 & 78.39 & 467.10 & 482.49 & 1303.83 \\
\hline$\frac{\pi}{2}$ & Total & 19221.57 & 1686.42 & 1262.34 & 15648.0 & 2478.15 & \\
\hline
\end{tabular}

In contrast, a shrinkage was evident in the area of shrub and grass lands (2,373.12 ha) between 1972 and 1986, although, at the same time it gained areas from the classes of bare land ( $538.56 \mathrm{ha})$, settlement (706.68 ha), cultivated land (7245.72 ha), and forest land (2297.16 ha).

In the second study period, 1986-2008, similar pattern has been observed as the first one, the area of cultivated land increased by 2312.8 ha although its area simultaneously was lost to forest land (157.14 ha), bare land (432.27 ha), shrub \& grass land (5744.34 ha) and settlement (443.43 ha) (Table 6, Figure $3 \& 4)$. As seen in the Table 6, the most important contributors to the increase of cultivated land were shrub \& grass land (7175.43 ha), forest land (689.04 ha) and settlement (612.72 ha).

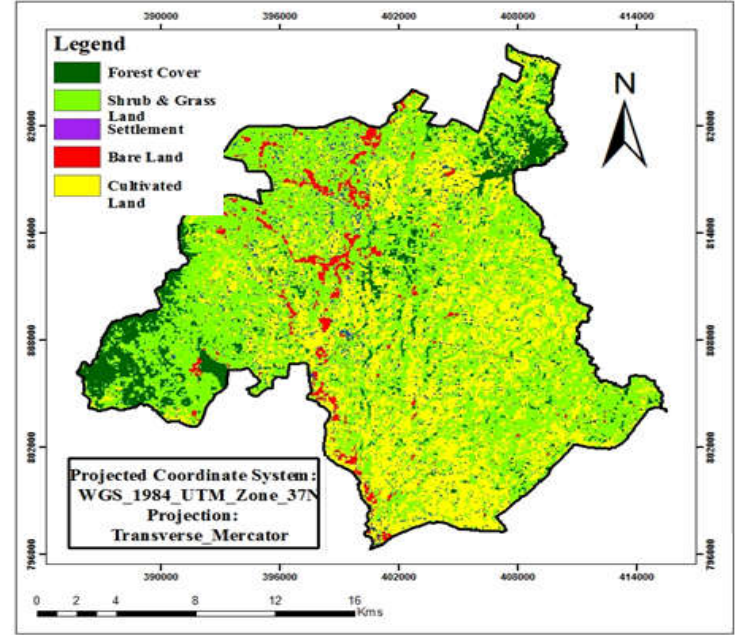

Fig 3. Land use/Land cover map of Bilate Alaba Subwatershed, 1986 
In contrary, areas of shrub and grass land decreased to 1118.40ha between 1986 and 2008, and it gained areas from classes cultivated land (7175.43 ha), bare land (1367.37 ha) and forest land (657.45 ha). In the third study period (2008-2017), the areas of settlement, bare land and cultivated land, have been increased by 748.76 ha, 589.85ha and 90.30ha respectively despite their initial areas in 2008 simultaneously were lost to forest land, shrub land \& grass land (Table 7, Figure 4 $\& 5$ ). As seen in the Table 7, the most important contributors to the increase of settlement, bare land and cultivated land were forest land and shrub land.

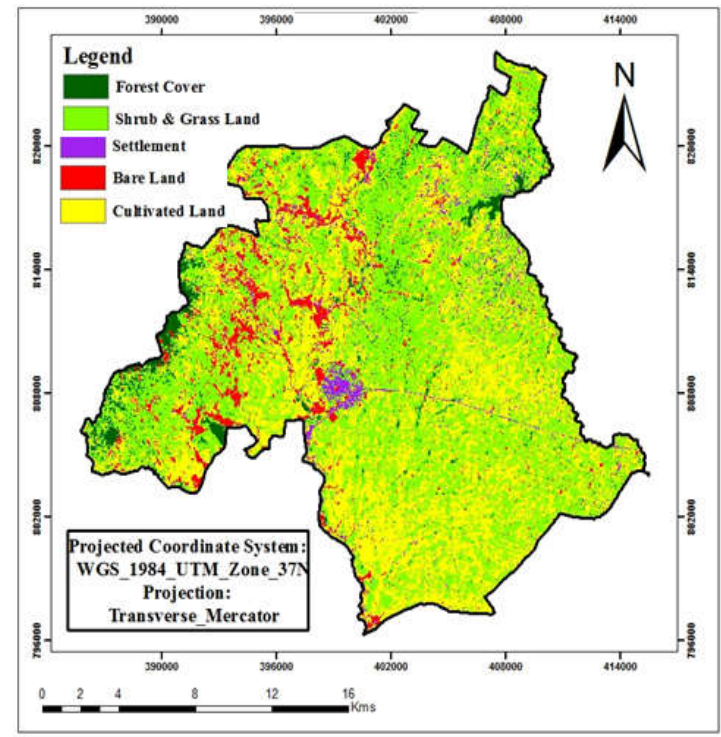

Fig 4 Land use/Land cover map of Bilate Alaba Subwatershed, 2008

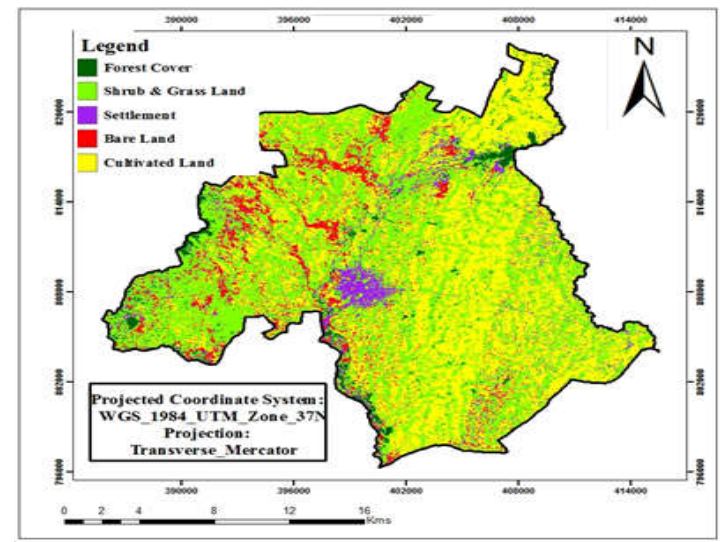

Fig 5. Land use/Land cover map of Bilate Alaba Subwatershed, 2017

Thus, from all classes in the subwatershed, shrub \&grass land (6426.63 ha) in the third period also noticeably continued to be the major area loser to cultivated land followed by settlement (779.83ha). In contrast, bare land and forest land classes were lost their original extents and transformed to other classes
(Table 7 and Figure 4). The area of settlement increased by 748.76 ha, however some portion of its extent was converted to shrub and grass land (450.11 ha), cultivated land (243.07 ha) and bare land (158.47 ha). This may be attributed to demand for more cultivation and settlement land caused by increment of population in the subwatershed (Wubie et al., 2016).

With regard to the annual rate of LULC changes, in the first study period, cultivated land as an important class for smallholders has been remarkably increased with $280.91 \mathrm{ha} /$ year rate (Table 8) while in the second period the rate increased by $105.13 \mathrm{ha} /$ year. In contrast to the cultivated land, the annual rate of forest land depletion was decreased by 8 folds in the third study period as compared to the 1972-1986. Similarly, bare land and shrub\& grass land decreased annually 225.26 ha/year \& 140.25ha/year in 1972-1986 study period. Similarly, the annual rate of forest land depletion was substantially increased from $2.61 \%$ in $1986-2008$ to $2.74 \%$ in $2008-2017$.

Five major land use and land cover types (cultivated land, bare land, settlement, forest land, shrub land \&grass land) were identified in all study areas. High values of overall classification accuracy (92.12\%$92.73 \%)$ and kappa coefficient (0.90-0.93) were attained; these indicated a strong agreement between the classified LULC patterns and the geographical data (ground truths). Then it is possible to use the output maps that meet the requirements for the intended application.

The increase in demand for wood for fuel and fodder, reduction of biodiversity, reduced land productivity, low income generation capacity, influence in microclimate of the study area resulted forest clearance, and land degradation, gully formation observed (Moges and Holden, 2009). The land use and land cover changes that were detected in the study areas revealed, in general, the greater areas of forest land, shrub land and grass land were transformed into cultivated land and settlement. The latter definitely imply how changes in land use and land cover causes land degradation; this finding is in agreement of previous scholars (Alemu et al., 2015; Zeleke and Hurni, 2001; Garedew et al., 2009). Generally, the annual rate of the agricultural expansion in the study period was $2.99 \%$; this result is in agreement with many studies in different part of the country (Garedew et al., 2009; Fisseha et al, 2011; Kidane et al., 2012). The annual rate of forest land conversion to other lands in the study period was severe and ranges between $2.61 \%$ and $2.74 \%$ in line with other scholars (Emiru et al., 2012; Moges and Holden, 2009; Tsegaye et al., 2010). 
Table 7: LULC Change Matrices of the Bilate Subwatershed (2008-2017)

\begin{tabular}{|c|c|c|c|c|c|c|c|}
\hline \multirow{8}{*}{ 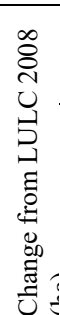 } & \multirow[t]{2}{*}{ LULC } & \multicolumn{6}{|c|}{ Change to LULC 2017 (ha) } \\
\hline & & $\begin{array}{l}\text { Shrub } \\
\text { \&Grass Land }\end{array}$ & Forest Cover & Settlement & $\begin{array}{l}\text { Cultivated } \\
\text { Land }\end{array}$ & Bare Land & Total \\
\hline & Shrub \&Grass Land & 10754.33 & 621.41 & 779.83 & 6426.63 & 593.71 & 19175.90 \\
\hline & Forest Cover & 1015.29 & 475.04 & 27.59 & 140.67 & 13.66 & 1672.25 \\
\hline & Settlement & 450.11 & 30.33 & 376.52 & 243.07 & 158.47 & 1258.49 \\
\hline & Cultivated Land & 5251.59 & 85.84 & 681.23 & 8166.96 & 1613.07 & 15798.69 \\
\hline & Bare Land & 883.73 & 7.04 & 144.65 & 732.49 & 697.84 & 2465.75 \\
\hline & Total & 18208.30 & 1270.93 & 2011.10 & 15738.32 & 3068.50 & \\
\hline
\end{tabular}

Table 8: Rate of changes in LULC classes (1972-2017)

\begin{tabular}{lllllll}
\hline & \multicolumn{2}{l}{1972 to 1986} & \multicolumn{2}{l}{1986 to 2008} & \multicolumn{2}{l}{2008 to 2017} \\
\cline { 2 - 7 } Land use and land cover & ha/year & $\%$ & ha/year & $\%$ & ha/year & $\%$ \\
\cline { 3 - 7 } Cultivated land & 280.91 & 2.99 & 105.13 & 0.79 & 10.03 & 0.06 \\
Settlement & 71.43 & 22.46 & -2.53 & -0.19 & 83.20 & 6.59 \\
Shrub \& Grass Land & -140.25 & -0.63 & -50.84 & -0.25 & -112.59 & -0.59 \\
Forest land & 13.14 & 0.35 & -103.41 & -2.61 & -46.16 & -2.74 \\
Bare Land & -225.26 & -5.04 & 52.90 & 4.02 & 65.54 & 2.64 \\
\hline
\end{tabular}

Human responsible for the conversion of land use change mainly destruction of forest for socioeconomic purpose and income generating which are linked to population growth. Forest were cleared for the purpose of agricultural land expansion as indicated by key informant discussion, and family having large number livestock's was an indication of wealth status in the society, as a result overgrazing was the major threat of land productivity in the Subwatershed. In the study area, fire wood and cow dung are major sources of household energy for cooking and heating purpose. Moreover, sales of wood and wood products is a means for low income individuals especially women, un-aware of land use policy for end users contributed to mismanagement of forest and land resources.

Conclusion: Multi-temporal Landsat data and GIS had potential to make study on land use and land cover dynamics, and used to establish major decision for effective natural resource management as well as planning. Avoiding deforestation and overgrazing through awareness would enhance livelihood diversification and proper management of livestock both quantity and quality (reducing the number of cattle based on carrying capacity and improve the breeds) with appropriate feed management at rural areas. The need for appropriate intervention of rural land policies and active participation of smallholders in the sustainable management of forest resources is crucial to prevent the forest resources.

\section{REFERENCES}

Abate, A; Lemenih, M (2014). Detecting and Quantifying Land Use/ Land Cover Dynamics in Nadda Asendabo Watershed, South Western Ethiopia. Inter. J. Environ. Sci. 3(1): 45-50.
Alemu, B; Garedew, E; Eshetu, Z; Kassa, H (2015). Land use and land cover changes and associated driving forces in North Western Lowlands of Ethiopia. Inter. Res. J. Agric. Sci. \& Soil Sci. 5(1): 28-44.

Anderson, JR; Hardy, EE; Roach, JT; Witmer RE (1976). A land use and land cover classification system for use with remote sensor data. Us geological survey professional paper, 964. A revision of the land use classification system as presented in U.S. Geological survey circular 671 Washington, United States Government Printing Office.

Ayalew, D (2008). Remote sensing and GIS-based Land use and land cover change detection in the upper Dijo river catchment, Silte zone, Southern Ethiopia.

Babiso, B; Senbetie, T; Aklilu, B (2016). Land use/Land Cover Dynamics and its Implication on Sustainable Land Management in Wallecha Watershed, Southern Ethiopia. Global J. Sci. Frontier Res. Environ. Earth Sci. 16 (4):49-63.

Bewket, W (2002). Land cover dynamics since the 1950s in Chemoga Watershed, Blue Nile Basin, Ethiopia. Mt. Res. Dev. 22: 263-269.

Central Statistical Authority (CSA). 2007. Summary and Statistical Report of the 2007 Population and Housing Census; CSA: Addis Ababa, Ethiopia.

Congalton, R.G; Green, K (1999). Assessing the accuracy of remotely sensed data: Principles and Practices. Lewis Publisher. Boca Raton, London, New York, Washington D.C 
Emiru, N; Gebrekidan, H; Tibebe, D (2012). Analysis of land use/land cover changes in Western Ethiopian mixed crop-livestock systems: The case of Senbat watershed. J. Bio. Environ. Sci. 2(3): 817

Eshetu, Z; Högberg, P (2000). Reconstruction of forest site history in Ethiopian highlands based on natural abundance of soils. Ambio J. Human Environ. 29: 83-89

Fentahun, T; Gashaw, T (2014). Evaluation of land use/land cover changes in Bantnek watershed, Ethiopia. Civ. Environ. Res. 6(7): 90-94.

Fisseha, G; Gebrekidan, H; Kibret, K; Yitaferu, B; Bedadi, B (2011). Analysis of land use/land cover changes in the Debre-Mewi watershed at the upper catchment of the Blue Nile Basin, Northwest Ethiopia. J. Bio. \& Environ. Sci. 1 (6): 184-198.

Foody, G (2002). Status of land cover classification accuracy assessment. Remote Sens. Environ. 80(1): 185-201.

Garedew, E; Sandewall, M; Söderberg, U; Campbell, B. M (2009). Land-use and land-cover dynamics in the Central Rift Valley of Ethiopia. Environ. Manage. 44: 683-694.

Giri, C; Zhu, Z; Reed, B (2005). A comparative analysis of the global land cover 2000 and MODIS land cover data sets. Remote Sens. Environ. 94: 123-132.

Girma, H.M; Hassen, R.M (1997). Drivers of land use change in Southern Nations, Nationalities, and People regional State of Ethiopia. Afr. J. Agric. Res. Econ. 9 (2):148-164.

Gizachew, A (2014). Geographical information system (GIS) based land evaluation for cash and perennial crops in East Amhara region, Ethiopia. J. Environ. Earth Sci. 4(19): 18-22.

Hurni, H; Tato, K; Zeleke, G (2005). The implications of changes in population, land use, and land management for surface runoff in the Upper Nile Basin Area of Ethiopia. Mt. Res. Dev. 25: 147154.

IPMS (2005). Alaba pilot learning woreda diagnosis and program design.
Jensen, J (2007). Remote sensing of the environment: An earth resource perspective, 2nd Edition. Pearson Education, Inc.

Kassa, T; Mulu, H (2012). Land suitability characterization for crop and fruit production in Midlands of Tigray, Ethiopia. Momona Eth. J. Sci. 4(1): 64-76.

Kidane, Y; Stahlmann, R; Beierkuhnlein C (2012). Vegetation dynamics, and land use and land cover change in the bale mountains, Ethiopia. Environ. Mon. Assess. 184: 7473-7489.

Kidanu, S (2004). Using Eucalyptus for Soil \& Water Conservation on the Highland Vertisols of Ethiopia. Ph.D. Thesis, Wageningen University and Research Centre, Wageningen, The Netherlands.

Lambin, E.F; Geist, H.J; Lepers, E (2003). Dynamics of land-use and land-cover change in Tropical regions. Ann. Rev. Environ. Res. 28(1): 205-241.

Lemenih, M; Teketay, D (2004). Potentials of plantation forests in fostering the restoration of native flora and fauna at degraded sites in Ethiopia: A review of Ethiopia. J. Biol. Soc. 3: 81-111.

Mas, J.F; Velázquez, A; Díaz-Gallegos, J.R; MayorgaSaucedo, R; Alcántara, C; Bocco, G; Castro, R; Fernández, T; Pérez-Vega, A (2004). Assessing land use/cover changes: A nationwide multi-date spatial database for Mexico. Inter. J. Appl. Earth Obs. Geo. 5: 249-261.

Moges, A; Holden, N. M (2009). Land cover change and gully development between 1965 and 2000 in Umbulo Catchment, Ethiopia. Mt. Res. Dev. 29: 265-276.

Mohammed, A (2004). Land suitability in the Jelo Catchment, Chercher Highlands of Ethiopia. Doctoral Dissertation, University of Free State, Blomfontein, South Africa.

Prenzel, B (2004). Remote sensing-based quantification of land-cover and land-use change for planning. Pro. Plan. 61: 281-299.

Rembold, F; Carnicelli, S; Nori, M; Ferrari, G.A (2000). Use of aerial photographs, Landsat TM imagery and multidisciplinary field survey for land-cover change analysis in the lakes region 
(Ethiopia). Inter. J. Appl. Earth Obs. Geo. 2: 181189.

Tekle, K; Hedlund, L (2000). Land cover changes between 1958 and 1986 in Kalu District, Southern Wello, Ethiopia. Mt. Res. Dev. 20: 42-51

Tsegaye, D; Moe, SR; Vedeld, P; Aynekulu, E (2010). Land-use/cover dynamics in northern afar rangelands, Ethiopia. Agri. Eco. Environ. 139: 174-180.

Vitousek, P.M.; Mooney, H.A.; Lubchenco, J.; Melillo J.M. 1997. Human domination of Earth's. Ecosystem. 277, 5325.
Wubie, M.A; Mohammed, A; Melanie, D.N (2016). Patterns, causes and consequences of land use/land cover dynamics in the Gumara watershed of Lake Tana basin, Northwestern Ethiopia. Environ. System Res. 5: 1-12.

Yizengaw, $T$ (1994). An approach towards a macrscale land evaluation as a basis to identify resource management options in central Ethiopia. Doctoral Dissertation, University of Ghent, faculty of sciences. International training center for post graduate soil scientist and Ghent University, Ghent.

Zeleke, G; Hurni, H (2001). Implications of land use and land cover dynamics for mountain resource degradation in the Northwestern Ethiopian highlands. Mt. Res. Dev. 21: 184-191 